\title{
Essais
}

ESSAIS

Revue interdisciplinaire d'Humanités

Hors-série 4 | 2018

Stanley Kubrick

\section{Dear Arthur, what do you think?": The Kubrick- Clarke collaboration in their correspondence from the Smithsonian and London Archives}

\section{Simone Odino}

\section{(2) OpenEdition \\ Journals}

Electronic version

URL: http://journals.openedition.org/essais/707

DOI: 10.4000/essais.707

ISSN: 2276-0970

\section{Publisher}

École doctorale Montaigne Humanités

\section{Printed version}

Date of publication: 1 July 2018

Number of pages: 173-191

ISBN: 979-10-97024-04-8

ISSN: $2417-4211$

Electronic reference

Simone Odino, " Dear Arthur, what do you think?": The Kubrick-Clarke collaboration in their correspondence from the Smithsonian and London Archives », Essais [Online], Hors-série 4 | 2018 Online since 01 December 2019, connection on 16 December 2019. URL : http:// journals.openedition.org/essais/707; DOI : 10.4000/essais.707 


\section{"Dear Arthur, what do you think?" The Kubrick-Clarke collaboration in their correspondence from the Smithsonian and London Archives}

\section{Simone Odino}

During their work together on 2001: A Space Odyssey (1968), Stanley Kubrick would often close his letters to the English writer Arthur C. Clarke with the sentence "What do you think?" 1 . This expression immediately suggests a collaborative dimension not usually associated to the director; at least, not until the reassessment of his work that started after his passing, made possible by the donation, by the Kubrick Estate, of the director's vast collection of production materials to the University of Arts in London. The resulting Stanley Kubrick Archive has instigated a new wave of scholarly study of his films and production methods, of which one of the most significant results is indeed the reappraisal of Kubrick as collaborator, summarized as such by Peter Krämer: "Kubrick's role in the making of films was not much a question of making up his mind and then imposing his decisions on everyone else, but to select collaborators and establish work procedures which were likely to produce results he could not have come up with on his own".

The most celebrated of Kubrick's collaborations, namely his work with Clarke on 2001: A Space Odyssey, has usually been discussed only through the lenses of Clarke's early published memoirs about the making of the movie. ${ }^{3}$

1 For example in the letter from Kubrick to Clarke, 11 April 1966, Correspondence 1966 Jan-May, Box 4, Folder 2, Arthur C. Clarke Collection; Archives Department, National Air and Space Museum, Smithsonian Institution, Washington, DC.

2 Peter Krämer, Complete total final annibilating artistic control, in Tatjana Ljujic, Peter Krämer \& Richard Daniels (eds.), Stanley Kubrick New Perspectives, London, Black Dog, 2015, p. 361. See also Catriona McAvoy, Creating The Shining: Looking beyond the myths, in Ljujic, op. cit., p. 3280-307; James Fenwick, I.Q. Hunter \& Elisa Pezzotta, The Stanley Kubrick Archive: A Dossier of New Research, Historical Journal of Film, Radio and Television, 37:3, 2017, p. 367-372.

3 See Arthur C. Clarke, The myth of 2001, Cosmos - The Science-Fantasy Review, No.1, April 1969, p. 310-11; Clarke, The Lost Worlds of 2001, London, Sidgwick \& Jackson, 1972; Clarke, Son Of Dr. Strangelove, first published in Clarke, Report on Planet Three and other speculations, London, Corgi, 1969, p. 3244-55, reprinted in Ian MacAuley, (ed.), Greetings, Carbon-Based 
Mainly focused on the author's struggle to come up with a satisfying plot and, perhaps most infamously, on his efforts to finalize a deal for the publication of the book that the two were concurrently writing, these works have contributed to a misunderstanding about the relationship between the writer and the director, that has often described in the general press as difficult or conflicted, true to the usual narrative about Kubrick the "dictatorial genius". Actually, the two enjoyed a long friendship; the usually hard-to-please director said that his relationship with Clarke was one of the most "fruitful and enjoyable" 4 he ever had, and when the director passed away in 1999, the writer said "My professional career owes more to Stanley than to anybody else in the world."

By making use of the correspondence held in the Kubrick Archive and in the recently opened Arthur C. Clarke Collection in the Smithsonian Museum in Virginia, I will shed some light on the collaboration between the director and the writer on 2001: A Space Odyssey, using as case histories the key points in the evolution of the plot and the issue over the publication of the book. I will also cover their (so far) largely ignored collaboration in the development of a screenplay based on Brian Aldiss's short story Supertoys last all summer long in the early Nineties (a project eventually brought to the screen in 2001 by Steven Spielberg as A.I.: Artificial Intelligence), to compare the two experiences and see if their attitudes, interests and working methods changed over time.

\section{"I was not interested in working with anyone else's ideas"}

The circumstances in which Kubrick first got in touch with Clarke are well known: in early 1964 a mutual friend, Roger Caras, suggested the writer as an appropriate collaborator for the director's intended movie "about extraterrestrials". "In his two previous works, Lolita and Dr. Strangelove, Kubrick had worked with the authors of the very texts he wanted to adapt (Vladimir Nabokov and Peter George); in general, all his movies originated from pre-existing literary works, because the director's main problem had always been "to find a strong story, from which he could develop a strong script"."

Bipeds!: Collected Essays 1934-1998, London, Voyager, 2001, p. 3259-263; Clarke, Back to 2001, first published in Clarke, 2001: A Space Odyssey, London, Legend, 1990, p. 39-18, reprinted in MacAuley, op. cit., p. 3ix-xix; Neil McAleer, Odyssey: The Authorized Biography of Arthur C. Clarke, London, Victor Gollancz, 1992, p. 3190-211.

4 Michel Ciment, Je suis un détective de l'Histoire..., L'Express, n.1312, 30 August - 5 September 1976, p. 318.

5 [Associated Press], Arthur Clarke hopes Kubrick will get Oscar posthumously, The Asian Age, 10 March 1999, p. 18.

6 McAleer, op. cit., p. 3190-191.

7 Filippo Ulivieri, The problem is to find an obsession: An Analysis of Stanley Kubrick's Numerous Unmade and Unfinished Projects, paper presented at "Stanley Kubrick: A Retrospective", De Montfort University, Leicester (UK), 11-13 May 2016. See also Peter Krämer, Adaptation 
But when the director set his mind on space, he didn't show interest in any specific books by the writer who had been recommended to him.

In his first letter written to Clarke on March 31, 1964 Kubrick did instead establish that he wanted to work with the English author on a movie that would explore "the reasons for believing in the existence of extra-terrestrial life" and "the impact (or lack of impact in some quarters) such discovery would have on Earth". ${ }^{8}$ As these subjects had been, in Clarke's own words, his "main preoccupation for the previous 30 years", 9 the writer replied enthusiastically and took the initiative, suggesting to use his short 1948 story The Sentinel ${ }^{10}$ as a possible basis for the movie: its core concept of an alien artifact discovered on the moon "would give all the excuse [they] needed for the exploration of the Universe". Kubrick and Clarke met for the first time in New York in April 22, 1964 and hit it off right from the start-talking, on their first day together, "for eight solid hours"; ${ }^{12}$ it was in one of their early conversations that a surprised Clarke found out that Kubrick did have in mind a pre-existing work he wanted to adapt. The director had been intrigued by a science fiction radio drama broadcast by BBC in late 1961, Shadow on the Sun, (a story about the invasion of alien lizards from Jupiter's moon Europa) to the point of asking Clarke to work on it as a starting point for their project. ${ }^{13}$ But only ten days after their first meeting, Clarke wrote the following note: "2 may. S. scrapped 'Shadow on the Sun' and agreed on 'Sentinel' basis for movie" 14 and Kubrick was promptly informed that the writer "was not interested in working with anyone else's ideas". 15

This usually overlooked false start in the history of 2001 suggests Clarke's importance in the project from the very beginning. It was the writer that convinced the director that The Sentinel had a greater dramatic potential for an exploration of mankind's destiny in space; Kubrick, at the same time, might

as Exploration: Stanley Kubrick, Literature, and A.I. Artificial Intelligence, Adaptation, 8 (3), p. 3372-382.

8 Kubrick to Clarke, 31 March 1964, "Clarkives" MSS 0052001 A Space Odyssey - General Notes, Box 103, Folder 4, Arthur C. Clarke Collection, Smithsonian.

9 Clarke, Son of Dr. Strangelove, in MacAuley, op. cit., p. 3259.

10 Clarke, Sentinel of Eternity, Ten Story Fantasy, Spring, 1951, p. 341-47; reprinted as The Sentinel in Clarke, Expedition to Earth, New York, Ballantine Books, 1953, p. 3155-167.

11 McAleer, op. cit., p. 3178.

12 Clarke, Son of Dr. Strangelove, in MacAuley, op. cit., p. 3261.

13 Jon Ronson, Lost At Sea: The Jon Ronson Mysteries, London, Picador, 2016, p. 177-178; Simone Odino, "God, it'll be hard topping the H-bomb": Kubrick's search for a new obsession in the path from Dr. Strangelove to 2001: A Space Odyssey, in James Fenwick (ed.), Understanding Stanley Kubrick's 2001: A Space Odyssey: representation and interpretation, Bristol, Intellect Books, forthcoming (2018).

14 Clarke, handwritten note, "Clarkives” MSS 0052001 A Space Odyssey - General Notes, Box 103, Folder 4, Arthur C. Clarke Collection, Smithsonian.

15 Clarke, Son of Dr. Strangelove, or how I stopped worrying and love Stanley Kubrick, first draft, p. 35, ibid. 
have realized that working with a brilliant and enthusiastically committed writer presented him with the opportunity to do what he hadn't managed to do ever since his first two juvenile works: to write an original story that dealt with a theme he cared for. ${ }^{16}$ It would take him and Clarke the next eighteen months to succeed in the task.

\section{"You can construct this as a logical reason for it if you try"}

It was Kubrick that decided to write a novelistic treatment instead of a traditional screenplay, and develop both a movie and a full-fledged book from it; the director thought that this would make him and Clarke "concentrate less on [a] scene than on the truthful working out of the many problems [of the plot]" ${ }^{17}$. On the strength of such treatment, the project was green-lighted by MGM in early January $1965^{18}$ and in the summer Clarke went back to Colombo (present Sri Lanka), while the director moved to Borehamwood, fifteen miles north of London, where the movie that was by then known as 2001: A Space Odyssey would be shot ${ }^{19}$. The plan was for the novel to be completed by mid-1965, and for the script to then be derived from it; but by the end of that summer, with the shooting of the movie now looming over the horizon, both texts -now being written "simultaneously, with feedback in both directions" 20 - were still incomplete and posed several problems still to be resolved. The two authors worked well together on the solution of such plot points -the most prominent being, no less, the very ending of the movie.

The novelistic treatment used to sell the project to $\mathrm{MGM}^{21}$ was indeed coherent, but ended rather abruptly: after pursuing various solutions, it was Kubrick who suggested, in October 1964, to have the astronaut Dave Bowman arrive, at the end of the trip through the so-called "Star gate", in a hotel room-type environment set up by aliens "to put our heroes at ease". 22 Bowman crossed a doorway in the room, encouraged by a voice on a telephone, and the story ended with him seeing the same alien artifact that had appeared in the prologue, set in primordial Africa: a transparent cube that had kick-started

16 See Ulivieri, op. cit.; Peter Krämer, Stanley Kubrick: Known and Unknown, Historical Journal of Film, Radio and Television, Vol. 37, No. 3, 2017, p. 3373-395; I.Q. Hunter, From adaptation to cinephilia: an intertextual odyssey, in Thomas Van Parys \& I.Q. Hunter, (eds.), Science fiction across media: adaptation/novelization, Canterbury, Gylphi, 2013, p. 343-63.

17 Hollis Alpert, Happiness is a film-maker in London, Saturday Review, 25 December 1965, p. 313. See also Krämer, Stanley Kubrick: Known and Unknown, p. 19-20.

18 McAleer, op. cit., p. 3201.

19 Clarke, The Lost Worlds of 2001, p. 337.

20 Ibid., p. 331.

21 Stanley Kubrick \& Arthur C. Clarke, Journey Beyond the Stars: A Film Story, Part. II, p. 3251, in Piers Bizony, The Making of Stanley Kubrick's 2001: A Space Odyssey, Cologne, Taschen, 2014.

22 Clarke, The Lost Worlds of 2001, p. 333. 
human evolution by influencing the minds of a group of ape-men. The effect that the cube would have on the astronaut was only implied by the text to be of a similar nature, but it was left entirely to the viewer's imagination.

In the attempt to avoid an ending that worked on paper, but that in a movie would have made people -Clarke said- "queuing at the box office to get their money back"23, the two gave way, in July 1965, to the temptation of showing a "majestically tall and graceful extra-terrestrial creature" ${ }^{24}$ that would take the astronaut's hand, "looking not unlike a parent leading his child". ${ }^{25}$ This was abandoned, too, in favor of what Clarke first introduced in an August 24, 1965 letter to Kubrick; that is, the idea of actually showing Bowman's transformation while he was sleeping in the hotel room: the astronaut would be seen "become transparent" 26 and be subject of a series of transformation "such as apparently being peeled away layer by layer". ${ }^{27}$ Kubrick's handwritten comment - "Interesting" 28 - was short but encouraging, but the very next day Clarke proposed a different, and more traditional, conclusion. Bowman would return to Earth after having gained knowledge of extraterrestrial science, with a "beautiful" spaceship gifted to him by the aliens; he wrote to Kubrick: "The ship is man's new tool -the equivalent of Moonwatcher's weapons. It symbolizes all the new wisdom of the stars. "29 The director expressed doubts about such an explicit explanation, and in a handwritten reply he explained: "I prefer present non-specific result for film. Maybe this can work in a book but it won't on film". ${ }^{0}$

Bowman's "transformation" would indeed have been a more elegant solution for what the director feared was the problem of the movie; that is, to potentially fall into the "silly simplicity" 31 typical of the science fiction stereotypes he had wanted to avoid ever since the beginning. It was Clarke that, in October 3, had the decisive idea on this direction: "Stanley on phone, worried about ending... gave him my latest ideas, and one of them suddenly clicked-Bowman will regress to infancy, and we'll see him at the end as a baby in orbit." 32 A couple of days later Clarke justified Bowman's transformation with

23 Ibid., p. 3188.

24 Stanley Kubrick, Arthur C. Clarke, 2001 A Space Odyssey, p. 374, "Clarkives" MSS 003.1: 2001: A Space Odyssey - Screenplay by ACC \& Kubrick 6/7/65, Box 103, Folder 1, Arthur C. Clarke Collection.

25 Ibid.

26 Clarke to Kubrick, 24 August 1965, SK/12/8/1/12, Stanley Kubrick Archive.

27 Ibid.

28 Kubrick's handwritten note, ibid.

29 Clarke to Kubrick, 25 August 1965, SK/12/8/1/11, Stanley Kubrick Archive, quoted in Peter Krämer, 2001: A Space Odyssey, London, British Film Institute, 2010, p. 347.

30 Kubrick's handwritten note, ibid.

31 Kubrick to Clarke, 11 April 1966, Correspondence 1966 Jan-May, Box 4, Folder 2, Arthur C. Clarke Collection.

32 Clarke, The Lost Worlds of 2001, p. 338. 
a "logical reason": it was "his image of himself at this stage of his development". 33 He would present Kubrick a readable version of the final chapter of the book by mid-January 1966 -a piece that the writer called "probably the most difficult thing I ve ever written" 34 ; the solution finally satisfied the director, who was reportedly "very happy" 35 with Clarke's work.

Another "logical reason" would be needed to explain the exact nature of the events in a key section of the movie: the trip of the spaceship Discovery to Jupiter, that had presented Kubrick and Clarke with even more problems, as the writer put it: "We had the beginning and (approximately) the end; it was the center portion which refused to stay in one place. I sometimes felt that we were wrestling with a powerful and uncooperative snake, anchored at both ends". ${ }^{36}$ In the final version of 2001: A Space Odyssey the real purpose of the mission is revealed to the astronaut Dave Bowman -and to the audience with himonly after the dramatic scene of the disconnection of Hal 9000. But in the drafts of the script developed by mid-1965, the astronauts Bowman and Poole and the on-board computer Athena, as it was by then called, were instead fully aware of their goals, which was to investigate Jupiter's moons in search of the destination of the signal emitted by the alien artifact dug up on the moon. The news of its discovery had indeed been made public, because "No one could give a completely plausible reason why [the aliens] might be hostile". ${ }^{37}$ All the excitement in the story was, by then, provided by a series of random in-flight accidents; Poole destroys the Discovery main antenna by mistake and is marooned in space, and the first hibernated crew member Bowman tries to revive dies because of a fault in the procedure. ${ }^{38}$ The accidents were not caused by a malfunctioning computer; Athena was only a laconic and, if anything, pedantic machine. When Bowman decides to retrieve a section of the antenna that is rapidly drifting away, she does not allow him to leave the Discovery because safety rules prevent the ship to be left unmanned; the baffled astronaut "curses angrily" 39 and loses precious time to re-program the computer; a scene that foretells the direction that the story would soon take.

The key change in the whole plot was suggested by Kubrick; perhaps confident in the potential of adding an element of mystery, he introduced the momentous idea that the real purpose of the mission could be kept a secret to

33 Ibid.

34 Clarke to Scott Meredith, 19 January 1966, Correspondence 1966 Jan-May, Box 4, Folder 2, Arthur C. Clarke Collection.

35 Ibid.

36 Clarke, The Lost Worlds of 2001, p. 3125.

37 Kubrick, Clarke, Journey Beyond the Stars, Part II, p. 370, in Bizony, op. cit.

38 Kubrick, Clarke, 2001: A Space Odyssey, p. 374, “Clarkives" MSS 003.1: 2001: A Space Odyssey Screenplay by ACC \& Kubrick 6/7/65, Box 103, Folder 1, Arthur C. Clarke Collection.

39 Ibid., p. 380. 
the crew. Clarke's reaction to the idea was not, at first, at all encouraging: in a letter from August 24, 1965 he wrote to the director "It's simply insulting to men of this calibre to assume that they can't keep a secret that hundreds of others must know" " 40 While the writer recognized that this was an element of surprise in the story, it looked to him "rather artificial and improbable" 41 , and it would have made the astronauts look "irresponsible". ${ }^{42}$ Kubrick did not justify his insight to the writer; in a handwritten comment he cleverly appealed, instead, to his sense of intellectual curiosity: "Don't agree. Only if you fail to try to make it work. [...] You can construct this as a logical reason for it if you try". 43

In September Clarke rejoined the director in Borehamwood and the two discussed the issue, coming up with a brilliant "logical reason": if Bowman and Poole didn't know the purpose of the mission, that meant that Athena was the only one who had to, because she had to run the ship in case of emergency. Hence, the computer needed to conceal to the astronauts the true nature of the trip; but this necessity interfered with the normal behavior of the computer, so that "it starts to make mistakes, which in turn give rise to desperate attempts to cover up the mistakes, eventually leading to multiple murder". ${ }^{44}$ We gather how Clarke was able to understand the possibilities that Kubrick's idea entailed from an October 12 note to the director, in which he suggested that instead of being "just an episode invented for excitement", the accidents depicted so far could become more integral to the film's story: "After all, our story is a quest for truth. Athenas [sic] action shows what happens when this truth is concealed". 45

A justification for the mission to be veiled in secrecy was therefore devised: as Heywood Floyd revealed in a scene cancelled from the movie, the intentions of the aliens were now deemed "potentially dangerous" and the information was now needed to be "kept on a need-to-know basis". ${ }^{46}$ The random mishaps of Bowman and Poole were therefore attributed to the computer's behavior, and the switch from Athena to HAL "the villain" was written into the screenplay between November and December $1965^{47}$, a mere two months before the beginning of the shooting of the Discovery sequence.

40 Clarke to Kubrick, 24 August 1965, SK/12/8/1/12, Stanley Kubrick Archive.

41 Ibid.

42 Ibid.

43 Ibid.

44 Peter Krämer, 2001: A Space Odyssey, p. 346.

45 Clarke to Kubrick, 12 October 1965, SK/12/8/1/12, Stanley Kubrick Archive, quoted in Krämer, 2001: A Space Odyssey, p. 346.

46 Stanley Kubrick, Arthur C. Clarke, 2001: A Space Odyssey, p. 3c127, "Clarkives" MSS 003.2: 2001: A Space Odyssey - Screenplay by ACC \& Kubrick, Box 103, Folder 2, Arthur C. Clarke Collection.

47 Ibid., p. 3c1-c128. 


\section{"I am certain it will all come out right in the end"}

Regarding the nature of the "accidents", Clarke would later admit that "HAL's episode is the only conventional dramatic element in the whole film. And so in that way you might say that it was rather contrived. You know, weve got two and a halfhours, something has to happen". ${ }^{48}$ Still, he and Kubrick had managed to devise two brilliant plot devices whose conception match the description given by Roger Caras of the collaboration between the two: "When those two were together, bouncing ideas off each other, it was like watching two intellectual duelists". ${ }^{49}$ From a creative standpoint things had worked well between the two, but the archives hold significant hints as well about the nature of their personal relationship.

In February 1967 Dave Maness, LIFE Magazine's editor, asked Arthur Clarke to "spice up" one of his articles about the making of 2001: perhaps there was "a crisis, an explosion, a showdown" 50 , in which Kubrick could have been depicted in a more sharp of caustic way? The writer answered: "There was never any friction at all-not even a single blow-up-during the working-out of the script. This makes it rather difficult to generate any excitement". ${ }^{51}$ Clarke's reply is especially significant in the light of some bitter remarks that he had made in the press, as in a March 1966 interview where he said that his work with Kubrick had been "a beautiful experience streaked with agony". ${ }^{52}$ As a matter of fact, Clarke was expressing his concerns about a very specific issue, that is, the delay in the publication of the book that he had developed from the initial novelistic treatment.

A substantial offer to publish the novel had arrived from Delacorte-Dell in early $1966^{53}$, and Clarke, that had devoted two years on the project delaying other sources of income, and had business activities in Ceylon that were going through financial troubles, felt that he needed the deal closed as soon as possible. From the spring to the summer of 1966 his agents pressed Kubrick as well as his lawyer Louis Blau: they were convinced that with the movie release planned, by then, for Easter 1967, it would have been impossible to put out the book on time if Kubrick did not green-light the offer. That, in turn, would

48 Gene Youngblood and Ted Zatlyn, Free Press Interview: Arthur C. Clarke, Los Angeles Free Press, 25 April 1969, reprinted in Stephanie Schwam (ed.), The Making of 2001: A Space Odyssey, New York, Modern Library, 2000, p. 259.

49 Piers Bizony, 2001 Filming The Future; Aurum Press, London 2000, p. 374.

50 David Maness to Clarke, 2 February 1967, VIP Letters, 1943-2004, Box 1, Folder 4, Arthur C. Clarke Collection.

51 Clarke to David Maness, 8 February 1967, ibid.

52 Godfrey Smith, Astounding Story! About a Science Fiction Writer!: Astounding Story!, New York Times, 6 March 1966, p. 3SM115.

53 Meredith to Ken McCormick, 13 March 1968, Correspondence 1968, Box 5, Folder 1, Arthur C. Clarke Collection. 
have jeopardized the chances of a serialized publication that, it was implied, would have guaranteed a vast amount of publicity to the movie; hence the substantial pressure that was put on Kubrick to finish his share of revisions on the manuscript in a timely manner. ${ }^{54}$ In October 1966 the director had promised Meredith a revised manuscript by February 5, 1967 "if humanly possible" 55 , but he wasn't able to respect this deadline, justifying his delay in delivering his share revisions with his busy schedule. The director actually felt the need to apologize, in a letter to the publisher Donald Fine: "I'm sorry about this. I am not usually a hang-up artist". ${ }^{56}$ To Clarke's agent, Scott Meredith, Kubrick delved into more detail about his excruciating daily routine : I get up at 7.00 am hit the studio by about 8.15 and begin a day that generally ends about $8.30 \mathrm{pm}$. I go home, say goodnight to the children, have dinner, work on the novel and go to bed around midnight. I do this seven days a week." 57

The initial general plan was to release the book before the movie (in a February 23, 1965 press release, MGM had announced that it would be "published this winter" ${ }^{58}$ ) but the evidence from the archives indicates that Kubrick was not under contractual obligation to sign any publishing deal or to commit to delivery dates: ever since the beginning, Clarke was an employee of Kubrick's Polaris Production company, and it was Polaris who had the final say. ${ }^{59}$ It was a position of strength that the director reminded to the writer in more than one occasion: "I have obviously had no opportunity at all to do my share of the revision to the book. It is my right to do this and I have repeatedly expressed to you how important I believe the revisions to be. "60 In another occasion, Kubrick wrote to Clarke that he was aware of the writer's concerns, "but this is one of those situations where there is no choice. I am certain it will all come out right in the end. I have no options now. I don't want the novel published in a form I consider unfinished." ${ }^{61}$ As a closing thought, Kubrick reminded Clarke that he had his

54 See the following letters from the Arthur C. Clarke Collection: Clarke to Mike Wilson, 12 March 1966, Correspondence 1966 Jan-May, Box 4, Folder 2; Clarke to Louis Blau, 16 March 1966, ibid.; Meredith to Clarke, 25 April 1966, ibid.; Clarke to Ian Macauley, $1^{\text {st }}$ February 1967, Correspondence 1967, Jan-May, Box 4, Folder 7.

55 Meredith to Blau, 26 October 1966, Correspondence 1966 July-December, Box 4, Folder 3, Arthur C. Clarke Collection.

56 Kubrick to Don Fine, 14 January 1967, SK/12/8/1/10, Stanley Kubrick Archive.

57 Kubrick to Scott Meredith, 5 October 1965, in Anon., The letters of Stanley Kubrick, The Telegraph, 7 July 2008 [http://www.telegraph.co.uk/culture/film/3555933/The-letters-ofStanley-Kubrick.html, last accessed 24 August 2017].

58 A.H. Weiler, Beyond the Blue Horizon, New York Times, 21 February 1965, p. 3X9.

59 Polaris Production to Clarke, 26 May 1965, "Clarkives" MSS 0052001 A Space Odyssey General Notes, Box 103, Folder 4, Arthur C. Clarke Collection.

60 Kubrick to Clarke, 12 July 1966, SK/12/8/1/12, Stanley Kubrick Archive, in James Chapman, Nicholas J. Cull, Projecting Tomorrow: Science Fiction and Popular Cinema, London, I.B. Tauris, 2013, p. 3100-101.

61 Bruce Handy 2001: A fllm Odyssey, Variety, 2 February 2018, p. 3197. 
own share of problems: "As you can imagine, there is a considerable amount of money involved in the film, too, and as many good reasons for people wanting it finished. The only difference has been that instead of continual pressure and oblique recriminations there has been an objective understanding of the problem, something that would be greatly appreciated regarding the novel." 62

It is tempting to see Kubrick's delay as yet another example of his legendary perfectionism, as Clarke did comment to one of the publishers interested in the book: "It is just that he is a perfectionist, and does not appreciate all the problems of the publishing business" ${ }^{3}$ Despite the concerns about his own financial situation, the writer remained remarkably sympathetic and supportive of his friend's difficult position; to a collaborator who complained about Kubrick's attitude, he observed that he didn't agree that the director was "insensitive to the needs of others - he is very sensitive but his artistic integrity won't allow him to compromise. I have to admire this attitude even when it causes me great inconvenience!". ${ }^{4}$ But Kubrick's insistence was not a mere matter of tight schedules, legal rights or "obsessive" control: the evidence suggests that the director felt it was his creative role in the writing that entitled him to make changes to the book up to the last minute -a book in which, for that matter, he held a significant $40 \%$ stake. $^{65}$

Ever since his early interviews the director made clear that his method of collaborating with his co-author consisted in doing one chapter each, and then "each other would kick the other's work around"; 66 also, the corrections Kubrick made to an article Clarke wrote about the making of 2001 suggest that he was keen in setting the record straight about the breadth of his input, as is evident from the following series of notes: "slight implication you alone did the story ideas", ${ }^{67}$ "again implication you do the creative writing", ${ }^{88}$ "the implication here is that you wrote novel alone" ${ }^{69}$ It was a contribution that Clarke did acknowledge with Kubrick's lawyer Louis Blau: "I must admit that [Stanley's] previous alterations [to the novel] have resulted in vast improvements", although he added "... but one has to stop somewhere". ${ }^{70}$ Kubrick's creative role in the

62 Ibid.

63 Clarke to William Jovanovich, 22 June 1966, Correspondence 1966 Jan-May, Box 4, Folder 2, Arthur C. Clarke Collection.

64 Clarke to Tom Craven, 29 January 1967, Correspondence 1967, Box 4, Folder 5, Arthur C. Clarke Collection.

65 McAleer, op. cit., p. 3197.

66 Alpert, op. cit., p. 313.

67 Arthur C. Clarke, Son of Dr. Strangelove, first draft, p. 38, “Clarkives” MSS 0052001 A Space Odyssey - General Notes, Box 103, Folder 4, Arthur C. Clarke Collection.

68 Ibid., p. 310.

69 Ibid., p. 311.

70 Clarke to Louis Blau, 16 March 1966, Correspondence 1966 Jan-May, Box 4, Folder 1, Arthur C. Clarke Collection. 
writing is certified by the fact that it was him that suggested to end the novel with the very same words that had already been used to end the prologue set in primordial Africa, that described what the ape-man Moonwatcher had felt after his evolutionary leap: "For though he was the master of the world, he was not quite sure what to do next. But he would think of something." ${ }^{\prime 1}$ In an August 24, 1965 letter Clarke wrote Kubrick: "I'm very happy about your finale ('He would think of something') and am drafting various approaches to it". ${ }^{72}$

Still, by the end of the project Kubrick might have felt that he had a moral obligation of sorts towards his collaborator. In later interviews he would gradually shift most of the credit for the novel to Clarke, and while the original plan was that the names on the book jacket would read "by Arthur C. Clarke and Stanley Kubrick"73, it was the director that eventually decided that it would be the writer alone to appear as author of the novel ${ }^{74}$. Clarke was later forced to admit that "In the long run, everything came out all right-exactly as Stanley had predicted"75: when the director eventually authorized the publication in March $1968^{76}$, apparently without any major revision ${ }^{77}$, even Clarke's agents had to admit that, appearing after the movie, the book would have an "unprecedented benefit": the millions already spent in promotion by MGM. ${ }^{78}$

2001: A Space Odyssey premiered in Washington in April 2, 1968, and became the critical and popular phenomenon that we all know; the novel, eventually published by New American Library, sold an estimate of 4 million copies by the end of the Sixties alone. ${ }^{79}$ The generous returns prompted Clarke to comment "Stanley Kubrick and I are laughing all the way to he bank". ${ }^{80}$

71 Stanley Kubrick, Arthur C. Clarke, Journey Beyond the Stars: A Film Story, Part I, p. 332, in Bizony, The Making of Stanley Kubrick's 2001: A Space Odyssey; Clarke, 2001: A Space Odyssey, London, Legend, 1990, p. 3297.

72 Clarke to Kubrick, 24 August 1965, SK/12/8/1/12, Stanley Kubrick Archive.

73 (Anon.), Kulerick and Clarke, Clarke and Kulerick (sic) Get Billing Problem for Space Film Solved, The Atlanta Constitution, Feb. 7, 1966, p. 37A; Clarke, The Lost Worlds of 2001, p. 331; Clarke to Kubrick, 4 March 1968, Correspondence 1968 Jan-Jun, Box 5, Folder 1, Arthur C. Clarke Collection.

74 Meredith to Blau, undated, SK/12/8/1/12, Stanley Kubrick Archive.

75 Clarke, The Lost Worlds of 2001, p. 49

76 Meredith to Ken McCormick, 13 March 1968, Correspondence 1968 Jan-Jun, Box 5, Folder 1, Arthur C. Clarke Collection.

77 Meredith to Louis Blau, undated, SK/12/8/1/12, Stanley Kubrick Archive.

78 Ibid.

79 Bizony, The Making of Stanley Kubrick's 2001: A Space Odyssey, p. 3422. The contract with The New American Library was signed on 22 March 1968; see 2001 Publicity, 1965-2003, Box 147, Folder 6, Arthur C. Clarke Collection.

80 Clarke, The myth of 2001, p. 311. 


\section{"Only you can write"}

In the years after 2001: A Space Odyssey Kubrick and Clarke kept in touch regularly, and for a brief period at the beginning of the Nineties it seemed there was a chance for the two to collaborate again. ${ }^{81}$ By then, the director had been working for a long time on the 1969 short story Supertoys Last All Summer Long ${ }^{82}$ by the English writer Brian Aldiss, set in an overpopulated future in which a childless woman adopts David, an android resembling a fiveyear-old boy. In 1982 Kubrick had signed Aldiss to work on Supertoys in order to develop it into a movie ${ }^{83}$; to the writer, who doubted that such a short story could be expanded into a full length script, the director replied: "Why not? I did it with Arthur Clarke's 'The Sentinel'. It's the same length, 2000 words" ${ }^{84}$, indeed a testament of how satisfied he had been of the collaboration with his old friend.

Kubrick would try to come to grips with the story for almost a decade, despite the help of other science fiction authors like Ian Watson and Bob Shaw ${ }^{85}$, but to no avail. After the release of Full Metal Jacket (1987), his work on Supertoys overlapped with the very same project he had discarded in 1964: Shadow on the Sun, whose rights he bought in 1988, and reportedly worked on for a while. ${ }^{86}$ It is unclear if the two projects where related to one another; still, the adaptation of the radio drama was evidently not meant to happen, because the director abandoned it again.

Clarke had consulted unofficially with Kubrick on Supertoys ever since 1989; when he wrote to the director on the last day of 1991, asking how the work on the script was evolving, Kubrick answered with a fax for which, in Clarke's own words, "many writers would have murdered their entire families": 87 "Only you can write 'Supertoys.' How much money would it take to get you to

81 In the decades that followed Clarke produced several sequels to 2001: 2010: Odyssey Two, New York, Ballantine, 1982; 2061: Odyssey Three, London, Grafton Books, 1987; 3001: The Final Odyssey, London, Voyager, 1997. Kubrick's involvement with 2010 and with Peter Hyams' movie 2010: The year we make contact (1984) seems to have been limited to the contractual negotiations needed because the sequel rights were co-owned by Polaris and MGM; see MGM-UA In Tug-Of-War With Phillips And 20"t-Fox Over Film Righs to "2010", Daily Variety, December 21, 1982, p. 1, 13; Peter Bart, Fade out: the calamitous final days of MGM, New York, Morrow, 1990, p. 63; McAleer, op. cit., p. 307-317.

82 Brian Aldiss, Supertoys Last All Summer Long, Harper's Bazaar, December 1969, p. 70-72, reprinted in Aldiss, Supertoys Last All Summer Long and Other Stories of Future time, London, Orbit, 2001, p. 1-11.

83 Brian Aldiss, Meet the man behind the myth, The Observer, 13 March 1999, p. 143.

84 (Anon.), Brian Aldiss : Young Turk to Grand Master, Locus Magazine, August 2000, [http:// www.locusmag.com/2000/Issues/08/Aldiss.html, last accessed 23 August 2017].

85 See Krämer, Stanley Kubrick: Known and Unknown.

86 Ronson, op. cit., Odino, op. cit.

87 Gary Dalkin, To The Last Word: an Interview with Sir Arthur C. Clarke, 21 April 2000, [http:// tothelastword.com/interviewer/arthur-c-clarke/, last accessed 23 August 2017]. 
do it? Name a figure". ${ }^{88}$ That was, the writer later said, "a challenge I couldn't resist" ${ }^{99}$ In his reply to the director he admitted that he was flattered by the offer, but he added that, besides the fact that noney was no longer a problem, his deteriorating physical conditions and the logistic challenge of working long distance would have been hard to overcome. He also added something that, arguably, even his most ardent fans wouldn't disagree with: "I still don't understand why you think I'm the person to help on Supertoys because this sort of emotional family drama is exactly the kind of thing I'm bad at". ${ }^{0}$

Still, Kubrick kept calling Clarke and sending him faxes, trying to lure him into working together again. In a letter to the writer the director commented the present state of the manuscript and recalled their successful past collaboration, in the attempt to convince him: "I think overall it lacks poignancy and rarely captures the sense of an intelligent but limited robot mind. You had it in the Dawn of Man [...]" Kubrick believed that there was "a major story here, with the subconscious, myth-making power 2001 had, and a degree of emotional involvement so rare in the genre". ${ }^{1}$

Although Clarke said later that "... really I did [Supertoys] because I owed him so much", ${ }^{2}$ the letters he wrote to his friend suggest that he was intrigued by the idea of seeing the headlines in newspapers "Clarke and Kubrick together again!". ${ }^{3}$ He therefore suggested to produce an outline of his take on the story, and if this was green-lighted by the director, he would then write a novel based on this and have Kubrick develop a screenplay from the novel, basically repeating the modus operandi that they had followed for 2001. Putting his other projects on hold, in late March 1992 Clarke began sending ideas to the director; because overpopulation was a key feature of the $21^{\text {st }}$ century envisioned by Aldiss in Supertoys, Clarke devised a short opening set in the year 2032 and featuring a black Pope (for the actor Clarke suggested Sydney Poitier) declaring that birth control was now condoned and authorized by the Catholic Church. ${ }^{94}$ Kubrick thought it was a promising start: "...now for just the next 37 thousands words". 95

As he advanced, though, Clarke became increasingly critical of the work previously made on the story (especially of the epilogue devised by Ian Watson before him, that featured robots from the future resurrecting David's mother

88 Dalkin, op. cit.

89 Dalkin, op. cit.

90 Clarke to Kubrick, 10 January 1992, Correspondence with Kubrick 1991-2005, Box 56, Folder 4, Arthur C. Clarke Collection.

91 Kubrick to Clarke, 19 January 1992, ibid.

92 Dalkin, op. cit.

93 Clarke to Kubrick, 10 January 1992, Correspondence with Kubrick 1991-2005, Box 56, Folder 4, Arthur C. Clarke Collection.

94 Clarke to Kubrick, 31 March 1992, ibid.

95 Kubrick to Clarke, 2 April 1992, ibid. 
from her DNA, that he called "scientific nonsense" ${ }^{\text {") }}$, and slowly moved away from it. This is evident in the five-page outline Clarke titled "Child of the sun", which was radically different especially in the conclusion; it described David awakening after 150 years in a world that has made contact with an alien superior civilization, that sends humans the instructions on how to build a starship. As the trip would last a thousand years, the ship would be crewed by androids, and David embarks with them as ambassador of Mankind. ${ }^{97}$

The themes touched upon in this ending are easily comparable with those in 2001; Clarke had indeed previously reminded Kubrick that his specialty was "hard sciences, and not even robotics, but space" ${ }^{98}$ The writer recalled years later that the outline he had sent to Kubrick was "Rejected instantly! [...] He hated it and asked me to tear it up" "99; actually, Kubrick wrote him a more subtle and amusing fax on May 26, 1992, in which he admitted he had "enjoyed [it] immensely". There was a problem, though: the director believed there was great material in the manuscript, and feared that Clarke had "not only thrown out the baby with the bath water, but the bathtub, the bathroom, indeed, the house itself". 100 The fact that Clarke wasn't sufficiently interested in the previously developed material left the director unsure about "what to do next". ${ }^{101}$

The writer replied mildly complaining about the lack of direction from Kubrick, that in the meantime had mysteriously stopped replying his faxes. Clarke had felt he had no chance but going ahead, developing the ideas he liked while ignoring those deemed "silly, unconvincing, or uninteresting..." 102 Replying in similar irony to Kubrick's "bathroom" fax, he admitted their artistic differences, but declared himself "still excited at the idea of working with you (and getting into the Guinness book of records as the only writer who's survived two rounds.)" 103

The main reason behind Kubrick's lack of response appears to be the concurring project he was working on. By the summer of 1992 the director had already developed two drafts of the script of Aryan Papers, an adaptation of Louis Begley's book Wartime Lies about a boy and his aunt hiding from the Nazi regime during the Holocaust, and was getting involved in the logistics

96 Clarke to Kubrick, 8 June 1992, ibid.

97 Arthur C. Clarke, Child Of The Sun, undated draft, ibid.

98 Clarke to Kubrick, 10 January 1992, ibid.

99 Gregory Feeley, The Masterpiece a Master Couldn't Get Right, 18 July 1999, New York Times, [https://partners.nytimes.com/library/film/071899kubrick-ai.html?mcubz=0. Last accessed 28 August 2017].

100 Kubrick to Clarke, 26 May 1992, Correspondence with Kubrick 1991-2005, Box 56, Folder 4, Arthur C. Clarke Collection.

101 Kubrick to Clarke, 2 June 1992, ibid.

102 Clarke to Kubrick, 27 May 1992, ibid.

103 Clarke to Kubrick, 6 June 1992, ibid. 
attached to the intended shooting in Poland. ${ }^{104}$ Clarke, in the meanwhile, had several other book projects going on; the available correspondence suggests that the two had such a tight schedule that even on the occasion of Clarke's trip to London in July to celebrate his $75^{\text {th }}$ birthday they had not time to sit down and talk about Supertoys thoroughly. Kubrick intended to contact Clarke again once the writer got back to Sri Lanka, but after a month of silence, in September 6 the director wrote apologizing and telling him abruptly that he was about to start a new film. "...I believed it would be possible to handle the day to day demands of this and still have time to work things out with you. [...] I hope I haven't screwed up anything for you". ${ }^{105}$

The secrecy that Kubrick had considered as paramount for Aryan Papers had evidently prevented him to tell even to his friend what he was working on, as we see from Clarke's surprised reply: "I was quite taken aback by your fax of 6 September -I'd assumed that 'Supertoys' was your 'next film". ${ }^{106}$ On these terms, their second, short-lived collaboration ended, and Clarke wished his friend the best of luck for the continuation of his projects -after all, this would allow him to focus on his others businesses, that he admittedly considered "more exciting, as well as being all mine!" 107 ; it was something Kubrick had already realized when he had confessed the writer "I understand how you feel about re-working someone else's semi-story". ${ }^{108}$

The roughly 150 exchanges between Kubrick and Arthur C. Clarke held in their combined archives constitute an impressive amount of primary sources, especially when compared to other collaborations the writer developed with writers on movies he produced and directed (or researched and didn't direct). The Clarke collection now provides the opportunity to evaluate the other side of the creative process behind 2001, and the tentative findings included in this essay seems to both confirm and expand the conclusions of the authors that made use of the London Archive in the last decade: without relinquishing any control over the project, on 2001 Kubrick was remarkably capable of creating a "creative space" 109 in which his collaborator was put in the best position to contribute effectively to the final product.

104 Jan Harlan, Alison Castle, From Wartime Lies to "Aryan Papers", in Alison Castle (ed.), The Stanley Kubrick Archives, Cologne, Taschen, 2005, p. 3509; Artur Piskorz, Aryan Papers: The Polish Connection, Media -Kultura- Komunikacja społeczna, 12/2, 2016, p. 373-79.

105 Kubrick to Clarke, 6 September 1992, Correspondence with Kubrick 1991-2005, Box 56, Folder 4, Arthur C. Clarke Collection.

106 Clarke to Kubrick, 9 September 1992, ibid.

107 Clarke to Kubrick, 2 August 1992, ibid.

108 Kubrick to Clarke, 2 June 1992, ibid.

109 Interview with Mick Broderick included in Dr. Strangelove, or: How I Learned to Stop Worrying and Love the Bomb, Blu-Ray, Criterion, 2016. 
The correspondence between Kubrick and Clarke seems to indicate that their relationship might indeed have developed along the lines of what their mutual friend Roger Caras suggested: "Stanley is probably the only person in the last forty years that Arthur has had to take a back seat to. [...] Kubrick is much more the forceful personality of the two. Kubrick says yes, Kubrick says no; it is yes or no. Arthur says yes, Arthur says no; it is maybe." 110 Their exchanges show the director's skill in subtly directing his co-author, his determination in imposing his will on the book deal and the breadth of his creative input in the writing of the novel; still, from the very beginning Clarke proved that he was not only Kubrick's yes-man, or a mere sounding board. He pointed the project towards the right direction from the very beginning, supplied the director with his unique writing skills, and worked successfully towards the solution of plot points, as well as being a relentless supporter of the project both in public and in private.

By comparing their collaboration on the seminal 1968 science fiction movie with the subsequent failed attempt in working on Supertoys it seems, nevertheless, that the success of the Kubrick-Clarke collaboration on 2001 did not rest only in the immediate connection and mutual respect between them -the aspect that Caras described as a fruitful "cerebral marriage". ${ }^{111}$ The production of the "proverbial 'really good' science-fiction movie" 112 was a success because the director trusted the writer enough to expand the scope of his original vision "in time and space" ${ }^{113}$, and because Clarke was intelligent enough in following the director's lead; but even more importantly, on that project they shared a definite goal and a keen involvement with the themes they were dealing with -that is, the impact of the discovery of extraterrestrial life on mankind.

On this regard, their subsequent collaboration on the development of Supertoys, although of lesser importance when compared with the extent of the work produced by the other writers Kubrick worked with during the convoluted development of what eventually became Spielberg's A.I. ${ }^{114}$, is a sort of mirror image to their previous work together. Supertoys was not Clarke's story,

110 McAleer, op. cit., p. 3202.

111 Smith, op. cit.

112 Samuel Wigley, The letter from Stanley Kubrick that started 2001: A Space Odyssey, 9 June 2016, British Film Institute website, [http://www.bfi.org.uk/news-opinion/news-bfi/features/letterstanley-kubrick-started-2001-space-odyssey. Last accessed 30 March 2018].

113 Clarke, Son Of Dr. Strangelove, in MacAuley, p. 3262.

114 See Jan Harlan, Jane M. Struthers, A.I. Artificial Intelligence from Stanley Kubrick to Steven Spielberg: The Vision Behind the Film, London, Thames \& Hudson, 2009; A. Castle, Stanley Kubrick's A.I., in Castle, The Stanley Kubrick Archives, p. 3504-508; Peter Krämer, Spielberg \& Kubrick, in Nigel Morris (ed.), A Companion to Steven Spielberg, Chichester, Wiley Blackwell, 2017, p. 3195-211. 
but Aldiss's; the writer, admittedly working on the project only out of a debt of gratitude, wasn't involved as he had been with his own The Sentinel, and couldn't cope with the director's requests. Supertoys wasn't Shadow on the sun either, because this time, Kubrick -increasingly frustated- was not willing to see the project deviate from a story he had cherished for so long, and that he had envisioned to expand into a "sentimental, dream-like fable".115

The available evidence suggests that Clarke was not particularly hurt by Kubrick's decision to abandon Supertoys (the two would later meet again in 1994, and would keep in contact regularly until the director's death in 1999); still, when the director surprised him with his last communication about his "new" next film, Clarke could not let him get away without one of the jokes he was famous for, sending his agents a fax that at the same time vouches for the unflappable humor of the English author and the inevitable difficulties that most writers experienced when dealing with the demanding and "stimulating, occasionally exasperating - but great fun" 116 director: "Im thinking of writing a piece entitled "If Stanley Kubrick calls, say I’m out." 117

\title{
Simone Odino \\ simoneodino@gmail.com
}

\begin{abstract}
From their fruitful four-years partnership on one of the watershed in the history of movies, 2001: A Space Odyssey (1964-68) to the unsuccessful effort -in the early 90's- of developing a story based on Brian Aldiss's short story Supertoys Last All Summer Long (eventually brought to the screen by Steven Spielberg as A.I.: Artificial Intelligence), Stanley Kubrick and Arthur C. Clarke enjoyed a long friendship that lasted until their deaths, and that has been described as a "successful cerebral marriage"; the two constantly stimulated one another with a flow of ideas and challenges, ever since the first letter written by the director on March 31, 1964, where he mentioned his intention to work with the writer on the "the proverbial 'really good'science-fiction movie".

Usually discussed only through the lenses of Clarke's published memoirs about the making of 2001: A Space Odyssey, the relationship between the writer and the director has often been described as difficult or conflicted, true to the usual narrative about Kubrick the "dictatorial genius". By making use of the correspondence held in the Kubrick Archive and in the recently opened Arthur C. Clarke Collection in the Smithsonian Museum in Virginia, I will shed some new light on their collaboration on 2001, using as case histories the key points in the evolution of the plot and the issue over the publication of the book. I will also cover their (so far) largely ignored collaboration in the development of Supertoys to compare the two experiences and see if their attitudes, interests and working methods changed over time.
\end{abstract}

115 John Baxter, Stanley Kubrick: A Biography, New York, Carroll \& Graf, 1997, p. 3355.

116 [Associated Press], op. cit.

117 Clarke to [Jack and Jacqueline?], undated, Correspondence with Kubrick 1991-2005, Box 56, Folder 4, Arthur C. Clarke Collection. 


\section{Keywords}

Kubrick, Clarke, 2001, Odyssey, collaboration.

\section{Résumé}

De leur collaboration fructueuse sur l'un des films les plus marquants de l'histoire cinématographique, 2001 : L'odyssée de l'Espace (1964-1968) jusqu'à leur tentative avortée, dans les années 90, pour développer une histoire inspirée de la nouvelle Supertoys Last All Summer Long de Brian Aldiss (finalement adaptée par Steven Spielberg avec I.A. : Intelligence Artificielle), Stanley Kubrick et Arthur C. Clarke entretinrent une longue amitié jusqu'à leur mort, qui fut décrite comme un " heureux mariage cérébral "; les deux hommes se stimulaient l'un l'autre en s'échangeant des idées et se lançant des défis, et ce depuis la première lettre écrite par le réalisateur le 31 mars 1964, dans laquelle il fait part de son intention de collaborer avec l'auteur pour créer "le tant attendu "premier chef d'œuvre" de science-fiction au cinéma".

La relation qui s'établit entre l'écrivain et le cinéaste, essentiellement envisagée à travers le prisme des déclarations de Clarke au sujet du tournage de 2001 dans ses Mémoires, fut souvent décrite comme difficile voire conflictuelle, en accord avec l'image d'Épinal de Kubrick, le "génie dictatorial ». Grâce à l'étude de la correspondance conservée aux Archives Stanley Kubrick ainsi que dans la collection Arthur C. Clarke récemment ouverte au musée Smithsonian de l'état de Virginie, cet article propose de ré-explorer cette collaboration en se concentrant sur certains moments cruciaux dans l'évolution du script de 2001 ainsi que sur les problèmes liés à la publication du roman éponyme. Enfin, nous reviendrons sur la seconde collaboration des deux artistes, actuellement peu étudiée, lors de l'adaptation de Supertoys ; nous pourrons ainsi comparer ces deux expériences et considérer les évolutions quant aux attitudes, aux méthodes de travail et aux intérêts du duo à travers le temps.

\section{Mots-clés}

Kubrick, Clarke, 2001, Odyssée, collaboration. 


\section{BIOGRAPHIC NOTE}

Simone Odino is a public librarian and archivist in Bologna (Italy), where he studied Political Science. For the last four years he has been actively researching the movie 2001: A Space Odyssey conducting interviews with cast and crew and visiting archives in the United Kingdom, the United States and Italy. An extended version of a presentation given at the Stanley Kubrick conference in Leicester (May 2016) is due to publication in the forthcoming book Understanding Kubrick's 2001: A Space Odyssey - representation and interpretation (Intellect, 2018). He also runs the website www.2001italia.it. 